Eur. Surg. Res. 1987;19:I-VI

Contents, Vol. 19, 1987

BII

S. Karger $\cdot$ Medical and Scientific Publishers

Basel $\cdot$ München $\cdot$ Paris $\cdot$ London $\cdot$ New York $\cdot$ New Delhi $\cdot$ Singapore $\cdot$ Tokyo $\cdot$ Sydney

Drug Dosage

The authors and the publisher have exerted every effort to ensure that drug selection and dosage set forth in this text are in accord with current recommendations and practice at the time of publication. However, in view of ongoing research, changes in government regulations, and the constant flow of information relating to drug therapy and drug reactions, the reader is urged to check the package insert for each drug for any change in indications and dosage and for added warnings and precautions. This is particularly important when the recommended agent is a new and/or infrequently employed drug.

All rights reserved.

No part of this publication may be translated into other languages, reproduced or utilized in any form or by any means, electronic or mechanical, including photocopying, recording, microcopying, or by any information storage and retrieval system, without permission in writing from the publisher or, in the case of photocopying, direct payment of a specified fee to the Copyright Clearance Center (see 'Information for Readers and Subscribers').

(C) Copyright 1987 by

S. Karger AG, P.O. Box, CH-4009 Basel (Switzerland) Printed in Switzerland by Thür AG Ofl7/8etdruck, Pratteln

\title{
Contents Vol. 19,1987
}

\section{No. 1 Original Paper}

Importance of the Preoperative Haemoglobin Concentration in Arterial Surgery

Matrai, A.; Kollar, L

Acute Thrombogenicity of a Compliant Polyurethane Urea Graft Compared with Polytet-

rafluoroethylene: An Experimental Study in Sheep

Lannerstad, O.; Bergqvist, D.; Dougan, P.; Ericsson, B.F.; Nilsson, B

Collagen Glycosylation in Human Granulation Tissue and Scar

Zanaboni, G.; De Luca, G.; Faga, A.; Salvini, R.; Castellani, A.A

Reticuloendothelial System Phagocytic Function in Obstructive Jaundice and Its Modifi

cation by a Muramyl Dipeptide Analogue

Pain, J.A.; Collier, D.St.J.; Ritson, A

Effects of Beta-Blocking Agents on Urinary Excretion of 3-Methylhistidine during Experi

mental Hyperthyroidism in Rats

Angerås, U.; Jagenburg, R.; Lindstedt, G.; Hasselgren, P.-0 .

Adaptive Changes in Rat Exocrine Pancreas following Subtotal Colectomy 
Büchler, ML; Malfertheiner, P.; Fischbach, W.; Beger, H.G.

Mortality in Rats on Long-Term Parenteral Nutrition

Nordstrand, K.; Melhus, O.; Eide, T.J.; Myhr, K.; Melbye, K.; Reikerås, O.; Sørlie, D.;

Giercksky, K.-E

Perfusion of Autologous Splenic Grafts in Correlation with Specific Immunological Func

tions - An Experimental Study in Pigs

Pimpl, W.; Thalhamer, J.; Pattermann, M

Use of Dextran to Prevent Pericardial Adhesions Caused by Maize Starch Powder

Reikerås, O.; Nordstrand, K.; Sørlie, D

\section{No. 2 Original Paper}

Profiles of Endogenous Prostaglandin F2«, Thromboxane A2 and Prostacyclin with regard

to Cardiovascular and Organ Functions in Early Septic Shock in Man

Oettinger, W.; Peskar, B.A.; Beger, H.G

Protection by Aminated Glucan in Experimental Endogenous Peritonitis

Almdahl, S.M.; Bøgwald, J.; Hoffman, J.; Giercksky, K-E.; Seljelid, R .

Effect of Splenectomy and Hemisplenectomy on Pneumococcal Infection and Bacteria

Clearance in the Rat

Pouchè, A.; Savoldi, F.; Colombi, A.; Tiberio, G.; Turano, A

86

Body Composition after 'Very-Little-Stomach' Biliopancreatic Bypass

Adami, G.; Gianetta, E.; Barreca, A.; Friedman, D.; Traverso, E.; Scopinaro, N. . . 91 Regional Blood Flow and Acid Secretion Associated with Damage and Restitution of the

Gastric Surface Epithelium in Cats

Dzienis, H.; Grønbech, J.E.; Varhaug, J.E.; Lekven, J.; Svanes, K

98

i $\gamma$

Myocardial Revascularization by $\mathrm{CO} 2$ Laser

Goda, T.; Wierzbicki, Z.; Gaston, A.; Leandri, J.; Vouron, J.; Loisance, D

Coagulation Defects during Extracorporeal Circulation in the Dog

Alvarez, J.; Escudero, C; Rodriguez, V.; Ortiz, J.; Castillo-Olivares, J.L

Effect of Intraarterial, Intraportal or Combined Norepinephrine Infusion on Hemorrhage

at Experimental Liver Trauma in the Rat

Vagianos, C; Zoucas, E.; Steen, S.; Bengmark, S

\section{No. 3 Original Paper}

Prolongation of Graft Survival in Allogeneic Pancreas and Liver Transplantation by

(-) 15-Deoxyspergualin

Thies, J.C.; Walter, P.K.; Zimmermann, F.A.; Dickneite, G.; Sedlacek, H.H.; Keller,

H.E.; Feifel, G

Autotransplantation of Splenic Tissue after Splenectomy in Rats Offers Partial Protection

against Intravenous Pneumococcal Challenge

Harding, B.; Kenny, F.; Given, F.; Murphy, B.; Lavelle, S

In vivo Dynamic "TMTc-HIDA Scintigraphy after Hepatocyte Transplantation: A New

Method for the Monitoring of Graft Function

Vroemen, J.P.A.M.; Linden, C.J. van der; Buurman, W.A.; Coenegracht, J.; Heirwegh,

K.P.M.; Kootstra, G.....

Composition of Free Fatty Acids and Adipose Tissue Triglycerides in Portacaval Shunted

Rats

Merli, M.; Sacchini, D.; Iapichino, S.; Anzà, M.; Berto, E.; Masella, R.; Mantovani, A.;

Riggio, O.; Cantafora, A

Liver Arterialization Prevents Thrombocytopenia after Portacaval Shunt in Rats

Aseni, P.; Beati, C.A.; Vertemati, A.; Meroni, A.; Belli, L

Lipid Peroxidation Is Not a Major Factor Involved in the Edema Formation in Perfused

Lungs

Risberg, B.; Smith, L.; Schoenberg, M.H.; Younes, M....

Experimental Study of Argon Laser-Induced Microthrombosis during $\mathrm{PGI}_{2}$ Infusion

Boncinelli, S.; Nerucci, P.; Marsili, M.; Lorenzi, P.; Fenati, E.; Di Stefano, L.C.; 
Biagiotti, S.; Giovannoni, L

Ultrasonic Duplex System to Facilitate Assessment of Portal Blood Flow Velocity

Regeneration of the Femoral Artery following Experimental End-To-End Anastomosis in

the Rat. An Ultrastructural Follow-Up

Maes, L.; Delvaux, G; Wu, J.X

\section{No. 4 Original Paper}

Long-Term Daily Study of Blood Volume in Cardiac Autotransplanted Dogs

Parent, R.; Stanley, P.; Chartrand, C.

Influence of Hemodilution on Hepatic Energy Metabolism in Rat

Tanaka, A.; Noguchi, M.; Morimoto, T.; Taki, Y.; Shimahara, Y.; Nakatani, T.; Tanaka,

K; Kamiyama, Y.; Yamaoka, Y.; Ozawa, K.

Measurement of Operative Plasma Endotoxin Levels in Jaundiced and Non-Jaundiced

Patients

Pain, J.A.; Bailey, M.E

Contents

$\mathrm{V}$

Manometric Characteristics of the Distal Oesophageal Sphincter and Patterns of GastroOesophageal Reflux in Healthy Volunteers and Patients

Zaninotto, G.; Costantini, M.; Bonavina, L.; Merigliano, S.; Baessato, ML; Iuliani, M.;

Anselmino, M.; Ancona, E

Anterior Gastric Stapling Combined with Posterior Truncal Vagotomy: An Experimental

Technique for Gastric Acid Reduction

Hendrickx, L.; Van Hee, R.H.; Van de Kelft, E.; Hubens, A

Role of the Proximal Duodenum in Gastrin Regulation following Antrectomy

Ratto, G.B.; Sacco, A.; Motta, G

Influence of a Jejunal Fistula on Gastric Emptying

Morrison, P.D.; Kelly, K.A

Transient Occlusion of the Left Anterior Descending Coronary Artery in Pigs

Galiñanes, M.; García-Dorado, D.; Elízaga, J.; Solares, J.; Riesgo, M.; Fdez-Avilés, F.;

Gomez Nebreda, M.J

\section{Abstracts}

17th Round Table Symposium on Applied Immunology

Axams, Tirol, February 3-5, 1986

\section{No. $5 \quad$ Original Paper}

Segmental Auxiliary Liver Transplantation in Dogs: A Search for an Ideal Graft - Illusion or Reality?

Lygidakis, N.J.; Chamuleau, R.A.F.M.; Rothuizen, J.; Grijm, R.; Baal, J.G. van; Kox, K.;

Altena, E. van; Joost, H.E. van; Brom, W.E. van den; Jöbsis, A.C.; Brummelkamp, W.H. 265 A Surgical Model of Fulminant Hepatic Failure in the Rabbit: Different Effects of End-

to-Side versus Small-Diameter Side-to-Side Portacaval Shunt

Fick, T.E.; Schalm, S.W.; Vlieger, M. de

Effects of Portacaval Shunt on the Cholesterol Metabolism of Genetically Hypercholester-

olemic Rats ('Rico' Strain)

Mathe, D.; Castaing, D.; Gigou, M.; Bismuth, H.; Cardona, E.; Lutton, C

Acute Responses of Blood Ketone Body Ratio following Devascularization and Revascularization of Rabbit Liver

Noguchi, M.; Tanaka, A.; Taki, Y.; Shimahara, Y.; Kamiyama, Y.; Ozawa, K

Expansion of Various Types of Heal Reservoirs in situ. An Experimental Study in Rats

Berglund, B.; Brevinge, H.; Kock, N.G.; Lindholm, E

Argyrophil Cells in the Rat Duodenum after Gastrectomy 
Morsiani, E.; Mazzoni, M.; Ricci, D.; Gorini, P 305

Endoscopic Evaluations of Potentially Ulcerogenic Drugs. A New in vivo Porcine Test

Model (with 1 color plate)

Hey, H.; Wamberg, T.; Rasmussen, M.; Jørgensen, F ....

Functional Recovery of the Exocrine Pancreas in Rats after Partial Resection

Sommer, $\mathrm{H}$

Experimental Pancreaticosplenic Composite Transplantation in the Pig. Operative Technique and Assessment of Graft Function Ganger, K.H.; Mettler, D.; Höflin, F.; Ruchti, C; Minnig, E.; Boss, H.P.; Schilt, W. . 323 Ischemic Heart Arrest: Nitrogenous Metabolism in Energy-Depleted Human Myocardium

Pisarenko, O.I.; Studneva, I.M.; Portnoy, V.F.; Arapov, A.D.; Korostylev, A.M. . . 329 VI

Contents

\section{No. 6 Editorial}

Prof. Dr. med. Dr. med. h.c. Walter Brendel - 65 Years

Messmer, K 337

\section{Original Paper}

Hemostasis after Open-Heart Surgery with Extreme or Moderate Hemodilution

Dale, J.; Lilleaasen, P.; Ereikssen, J.

Functional Effects of Phosphoenolpyruvate and ATP on Pig Hearts in Cardioplegia and

during Reperfusion. An in vitro Study with cardiopulmonary Bypass

Thelin, S.; Hultman, J.; Jakobson, S.; Juhlin, C; Hansson, H.E.; Ronquist, G..

Beneficial Effect of Thyroidectomy in Canine Hemorrhagic Shock

Shirakawa, Y.; Smith, R.A.; Shatney, C.H

Asanguineous Isolated Hyperthermic in vivo Perfusion of the Liver in the Rat

Adam, R.; Poggi, L.; Capron, M.; Morin, J.; Gigou, M.; Miramand, J.C.; Szekely, A.M.;

Houssin, D

Experimental Model of Extended Repeated Partial Hepatectomy in the Dog

Szawlowski, A.W.; Saint-Aubert, B.; Gouttebel, M.C.; Astre, C; Joyeux, H

Can Hepatocytes Proliferate when Transplanted in the Spleen? Demonstration by Autohis-toradiography in the Rat Nordlinger, B.; Wang, S.R.; Bouma, M.E.; Verthier, N.; Hillan, K.; Delelo, R.; Infante, R. 381

Decreased Reticuloendothelial Phagocytic Capacity in Cirrhotic and Portacaval Shunt Rats

Capron-Laudereau, M.; Gugenheim, J.; Gigou, M.; Crougneau, S.; Houssin, D.; Bis

muth, $\mathrm{H}$.

Effects of Different Graft Preparation Techniques on the Acute Thrombogenicity of Autol-

ogous Vein Grafts. An Experimental Study in Sheep

Lannerstad, O.; Dougan, P.; Bergqvist, D.

Author Index

Subject Index

Suppl. 1 European Society for Surgical Research

22nd Congress, Aarhus 1987

Abstracts

Editors: J.C. Djurhuus, H.S. Stødkilde-Jørgensen, E. Amdrup, C. Bünger, F. Gottrup, J. Ørnsholt 